\title{
MANAGEMENT ACCOUNTING FOR A PORTFOLIO OF PROJECTS TO SUPPORT ORGANISATIONAL VALUE MAXIMISATION
}

\author{
P.J. Viljoen \\ Department of Engineering and Technology Management \\ University of Pretoria, South Africa \\ philip.viljoen@up.ac.za
}

\begin{abstract}
The objective of management accounting is to provide management with the financial information that will enable them to make decisions that will result in increased profitability of their organisation. The management accounting of projects in a portfolio as proposed in the literature often presents major problems that prevent the achievement of this objective. These problems include how to estimate value in financial terms during the pre-project phase of the project life cycle as well as the difficulties with financial control of the portfolio of projects as they are conducted. A few case studies are presented highlighting, current practice and the negative effects being experienced. A simple throughput accounting model for the financial management of a portfolio of projects, that could lead to better management decisions and increased profitability of organisations, is proposed.
\end{abstract}

\section{OPSOMMING}

Die doelwit van bestuursrekeningkunde is om bestuur te voorsien met finansiële inligting wat hulle in staat stel om besluite te maak wat die winsgewendheid van die onderneming sal verbeter. Die bestuursrekeningkunde van 'n portefeulje van projekte wat in die literatuur voorgestel word, het 'n aantal probleme wat die bereiking van hierdie doelwit verhinder. Hierdie probleme sluit in hoe om ramings van waarde in finansiële terme te doen tydens die pre-projek fase van die projeklewenssiklus asook die probleme met finansiële beheer van die projekportefeulje soos dit uitgevoer word. 'n Aantal gevallestudies word aangebied wat huidige praktyke en die negatiewe effekte wat ondervind word toelig. ' $\mathrm{n}$ Eenvoudige deursetverrekeningsmodel vir die finansiële bestuur van ' $\mathrm{n}$ projekportefeulje word voorgestel wat kan lei tot beter bestuursbesluite wat die winsgewendheid van ' $n$ onderneming sal verbeter. 


\section{INTRODUCTION}

Many organisations operate through conducting multiple projects. Portfolios are groupings of projects that could be in different lifecycle stages. Examples of project portfolios are engineering projects in a factory, technology research and development projects, new product development projects, consulting projects, innovation projects, all the projects in a medium size company, or all the projects in a division of a larger company. Managers need to manage the projects as a group over time to gain a more holistic view of the projects that draw from a common pool of resources, to understand the interdependencies between related projects as well as to assess the overall risk the organisation is exposed to. Kaplan and Norton [1] view an aggregate project plan as equivalent to a portfolio of projects. A portfolio is often also referred to as a programme [2]. Benko and Mcfarlan [3] describe a company portfolio of projects as its future currency.

The management of a portfolio of projects includes decisions to maximize the portfolio value. Financial value is one of the elements of value and a management accounting system is necessary to provide the information to enable good portfolio decisions.

Management accounting is concerned with the future of an organisation whereas financial accounting is a record of the past. The data for management accounting are estimates of an unknown future while financial accounting records transactions that have actually taken place. The past is only used as one of the inputs of the estimation process in management accounting. The data used in management accounting can thus never be accurate (it is sometimes questioned whether the data used in financial accounting is accurate).

The management of a portfolio of projects requires decisions to be made to select the right project for investment from many candidates and to prioritise selected projects to direct the efforts of a limited set of resources [4]. If this is not done, projects could proliferate, scarce resources could be wasted on the wrong projects and very little real value would be realised for the organisation, all this while all and sundry are working hard.

Data on three financial factors needs to be considered in making decisions about financial value. These factors are:

- The expected inflow of money in the future after the projects have been completed,

- The expected outflow of money while projects are conducted, (these two money flows are combined in the term cash flow - the expected uses and sources of the cash resource of a company)

- The allocation of limited resources (resources other than cash).

This data is used to determine bottom line metrics such as the expected change in profitability, the return on investment and to assess the value which the organisation is capable of generating in the future. These estimates of the future are very uncertain and the assumptions it is based on are often ambiguous [2]. 
The current practice in management accounting is strongly influenced by a cost allocation paradigm in an effort to account for all costs of resources allocated to the project and in this way to manage scarce expensive resources. This paradigm is manifested in cost recovery approaches and Activity Based Costing (ABC) models. This is used to supply information to Activity Based Management systems designed to provide the vehicle for improvement [5]. All resource expenses such as salaries, equipment, technology and materials are allocated to all process activities.

Project plans consist of a network of defined activities. It is therefore relatively easy to allocate resource expenses. This research indicates that the cost allocation to project activities is typically based on the number of hours that resources are expected to work at tasks. The hours worked times the hourly rate of the resource determines a cost for the activity. The hourly rate includes fixed and variable salaries and often certain overhead costs. The activity costs is then used to determine expected project profitability and to make management decisions on selecting and prioritising projects. An unprofitable project will not be selected.

A number of case studies and a simulation are presented to demonstrate the negative results that this practice has on the value of a project portfolio.

Throughput accounting, that is not based on the allocation of costs, while explicitly accounting for the use of resources, is presented as an alternative that could result in improved decisions leading to more value to organisations.

The financial valuation of projects and a portfolio of projects as proposed by the literature are discussed in the next section to establish the theoretical framework for the case study research.

\section{VALUE OF A PROJECT PORTFOLIO}

To valuate a portfolio of projects the financial value of a single project needs to be estimated in such a way that the individual values can be combined in some way.

Luehrman [6] states that valuation always has to account for three fundamental factors. They are the quantum of cash flows, its timing and the level of risk or uncertainty. He ignores the allocation of other resources as a factor assuming that it is included in the estimated cash flows.

The data therefore required to determine the financial value of a project is the future project cash flow, when the flows are expected to occur and some indication of the level of uncertainty inherent to the flows. The uncertainty is influenced by external factors such as for example, the expected exchange rate in 5 years time, as well as possible decisions that could be made in the future.

The financial value of a project is finally expressed in terms of the profits that conducting the project will generate for the organisation as well as the rate of return, which is the ratio of the profit to the investment in the project [7]. 
The cash flow on a project occurs at different times. The time value of money therefore should be used in order to account for the different time periods as well as account for the opportunity to invest the money elsewhere during the time that cash is tied up in a project. It is necessitated by the assumptions that money is scarce (not available in unlimited supply) and that alternative investment opportunities exist (such as earning the risk free rate in a bank).

Calculation of present value (PV), net present value (NPV), discounted cash flow (DCF), internal rate of return (IRR) and economic value add (EVA) are traditionally done with the cash flow projections to provide a number that can be used to indicate the value of a project. These calculations take the different timeframes of the money flows into account and use a discount rate to normalise the flows to one timeframe (the present) to enable accumulation.

This valuation of a project reduces the uncertain cash flow estimates to a single number. There is a risk that this number is deemed to be accurate (since it has been calculated in a relatively sophisticated way) while it remains only an estimate. The valuation also does not take into account future decisions that could be made other than what has been assumed in the projected cash flows. The option always exists that a decision could be made to abandon a project at a later stage if new information indicates that projected cash flows will not generate profits or to invest more if later information indicates a bigger market or when a relatively inexpensive first phase is successful.

This is similar to the value of a stock option. It accounts for the future flow of money when the stock is sold or bought. An option is purchased to buy or sell a stock on or before an expiry date at the striking price [9]. At the expiry date the decision is made to exercise the option (buy or sell the stock) or to not exercise the option. The option view then essentially deals with the situation that money is invested now to enable a decision later. Without this initial investment the decision could never be made. This is very often the case in research and development projects or when new technologies are being developed, new markets are being explored or new products are being developed [4].

Luehrman [9] has developed a simplified way to use the Black Scholes model of valuation of a share option to determine a value of a project that accounts for future decisions. His approach maps five financial project variables onto the variables used in the Black Scholes model for European call options (the simplest form of options). These variables are:

- The present value of a project's operating assets to be acquired mapped as the price of the share - denoted as S,

- The expenditure required to acquire the asset mapped to the exercise price of the option - denoted as X,

- The length of time that the decision may be deferred mapped as the time to expiration of the option - denoted as $t$,

- The time value of money mapped as the risk free rate of return - denoted as $r_{\mathrm{f}}$, and 
- The riskiness of the project asset mapped as the variance on returns on the share denoted as $\sigma^{2}$.

With these variables he develops two metrics. The first is a ratio called modified net present value expressed as a ratio and denoted as $\mathrm{NPV}_{\mathrm{q}}$. It is determined by dividing $\mathrm{S}$ by the present value of $\mathrm{X}$. This metric accounts for the inflow and outflow of money as well as the reality that it occurs at different times. It includes the extra value that is possible because the decision impacting later cash flows is deferred. This extra value is contained in the present value of $\mathrm{X}$ as the interest earned over the period that the decision is deferred. He refers to this metric as the value to cost ratio.

The other metric is called cumulative volatility and is calculated as the square root of the variance $\left(\sigma^{2}\right)$ times the time $(t)-$ denoted as $\sigma \sqrt{t}$. This metric accounts for the uncertainty inherent in the estimate of the project cash flows over time.

A project can then be valued relative to other projects through plotting it in a two dimensional space using the two metrics as the vertical and horizontal axes.

The variance used in determining the cumulative volatility needs to be estimated from historical data. This data is often not available for projects and when available its accuracy is doubtful. It is for these reasons that a school of thought has developed that tends toward using the original estimates only as valuation tools and to use a reasonable range of the original estimates as an indication of uncertainty. This will be discussed further.

The allocation of resources is not explicitly accounted for in this approach. Current practices in use to include resource allocation are discussed in the next section.

\section{RESEARCH}

The research was carried out via a number of case studies conducted over a period of seven years as part of consulting assignments and student research and student assignments. The valuation of projects for decision making and financial control of projects were studied in a research and development organisation, a SAP implementation firm, the IT division of a large transport company offering IT supply chain solutions, a gold mine, a supplier of high-tech weapon systems, a supplier of large IT solutions to financial institutions, the IT divisions of three major retail banks, the innovation (product development) projects of an international supplier of fast moving consumer goods and the engineering projects at two factories. A total of 12 multi-project environments were included in the study.

In nine of the twelve cases cost accounting was applied to the valuation or costing of projects through the allocation of internal costs. The rationale is that all the costs of resources used on a project must be included in project cost to ensure that realistic estimates are made and to ensure that the real costs of projects are known. Costs of resources need to be recovered from the income generating activities (conducting of projects). The assumption is made that in this way the allocation of resources can be accounted for. Internal costs such as labour costs of internal resources, project 
managers and overhead are included as a cost item of work packages. It is calculated as the estimated duration of the work package multiplied by an hourly rate. The hourly rate of a resource is typically determined by dividing 160 (a standard number of working hours per month) into its monthly total cost of employment. These costs are also tracked when the project is conducted by requiring resources to report actual time spent on a work package through a time sheet system. Project profitability is then determined and used as performance metric of the project manager.

The duration of work packages is well defined and this allocation mechanism is considered to be accurate by all the companies using it. It is also considered to be an advanced project management tool that provides improved cost control on projects. The PMBOK ${ }^{\circledR}[8]$ refers to this approach as bottom-up cost estimating.

Resource costs allocated to activities could be categorised as internal and external costs for purposes of this research. Internal costs are those costs (salaries) that are paid to resources that are in the employ of the organisation and used across a number of projects, while external costs are costs of contractors, supplies and materials. External costs are only incurred as a result of conducting a project.

The percentage to total cost of internal resource costs varied significantly between the different cases. The capital intensity of the projects is inversely related to the percentage of internal costs. The more capital intensive the projects are (engineering projects), the smaller the percentage of internal costs allocated to total project cost. The level of outsourcing that is practised by the organisations also influenced this ratio. IT projects, consulting projects, research and development projects and product development projects have a high percentage of internal costs allocated where the level of outsourcing was low. A trend of increased outsourcing was however noted in most of the cases. The engineering departments that were studied used contracted draughtsman increasingly, for example. Outsourcing was minimal but not absent, where resources on projects were highly specialised such as for the SAP implementer, the supplier of high-tech weapons systems and the supplier of large IT systems.

The problem with the allocation of internal costs to projects is that management decisions are distorted and in many cases lead to the decrease of organisational financial performance as well as late delivery of projects. Organisational expenses that will not be impacted at all by the decision are included in the information that determines the decision. The problem is illustrated by means of a simulation in the next section.

Projections of cash flow are used as the basis of calculating NPV, IRR, NPV,$\sigma \sqrt{t}$ and EVA - metrics that are used to select and prioritise projects as indicated in the first section of this article. Additional cash does not flow when internal resources are used to conduct a project. Conducting the project does not cause additional money to be spent to pay for resources that are employed by the organisation. This money is spent in any case, whether the project is conducted or not, unless the resources are to be discharged at the end of the project - which is highly unlikely. With the exception of one case where the project manager's services were terminated at the 
end of the project, in all the cases studied, resources were not discharged when projects were concluded. They were redeployed to other projects or to operational duties. Evaluating a project on cash flows that will be incurred whether the project is conducted or not could distort the decision to the extent that the value of a portfolio of projects is reduced.

The degree of distortion depends on the capital intensity of the project. It is most apparent in low capital-intensive projects where internal costs are a high percentage of total project costs. The following table detailing the results of the simulation illustrates this. It demonstrates the effect on NPV (the dependent variable) for a fictitious project when the percentage of internal costs allocated as project expenses (the independent variable) is changed. The fictitious cash flows are -2 for 2 periods, -3 for 1 period, -5 for 1 period, 0 for 1 period, 1.5 for 2 periods and 1 for 10 periods. The discount rate is chosen as $1 \%$ per period. These parameters are chosen to give a marginally negative NPV when all costs are allocated to the project.

\begin{tabular}{|c|c|c|c|}
\hline $\begin{array}{c}\text { Allocated internal } \\
\text { cost as \% of total } \\
\text { project expense }\end{array}$ & $\begin{array}{c}\text { NPV when internal } \\
\text { costs are allocated } \\
\text { to the project }\end{array}$ & $\begin{array}{c}\text { NPV when internal } \\
\text { costs are not } \\
\text { allocated to the } \\
\text { project }\end{array}$ & $\begin{array}{c}\Delta \text { NP Cumulative } \\
\text { Net profit } \\
\text { contribution of the } \\
\text { project }\end{array}$ \\
\hline 10 & -0.01 & 1.15 & 2.2 \\
\hline 20 & -0.01 & 2.32 & 3.4 \\
\hline 50 & -0.01 & 5.82 & 7 \\
\hline 80 & -0.01 & 9.31 & 10.6 \\
\hline 90 & -0.01 & 10.48 & 11.8 \\
\hline
\end{tabular}

Table 1: Effect on profitability of allocating costs

Table 1 illustrates that a project that would probably not be selected as a result of a negative NPV should in fact be selected when internal organisational costs are not allocated to project cost. This is valid even if only $10 \%$ of the total project expenses are internal costs. If the project can be done mostly with internal resources $(90 \%$ of the project costs are allocated internal costs), then the project NPV could be 10.48. The last column shows the contribution to profitability that the project will provide for the different percentages of internal costs not allocated - ignoring the time value of money. This project would contribute 1 money unit to the profitability of the organisation over the 17 periods if no distinction is made between internal and external costs. If $90 \%$ of the project costs are internal costs, then the contribution to profitability is 11.8. Internal capacity will be utilised well. But the project will not be selected - it has a negative NPV.

This illustration raises the question whether and how internal capacity should be included in the decision to select and prioritise projects. The assumption is made that capacity is available in the organisation when internal costs are allocated to projects. The allocation of internal costs causes the project to not be selected. What would happen to the internal resources? They could be discharged and in this way reduce costs, but the capability to generate more money would then be lost and the capacity 
will no longer be available for other opportunities. This is the fundamental problem that is created by this practice. It can place an organisation in a death spiral that it can never recover from.

\section{THROUGHPUT ACCOUNTING}

Goldratt [10] developed a management philosophy that is known as the Theory of Constraints (TOC). One of the central tenets of this philosophy is that local management decisions must result in improved global system performance. The decision to activate a project (a local decision) to be worked on, for example, must result in increased financial bottom line performance (the global performance) of the organisation as a whole.

Goldratt defined three operational financial metrics for an organisation in order to have a simple set of intermediate global performance metrics that can be used at any level in an organisation. He defines Throughput $(\mathrm{T})$ as the rate that money is generated through sales. Throughput is calculated by deducting the true variable costs from the cash received from a sale. The term True Variable Cost (TVC) is used to emphasize that only costs that are incurred as a result of the sale (project) should be used in calculating the amount of money generated. Other costs are being incurred already and have no relevance to a decision to select a project, if these costs remain unchanged. This is a true cash metric that is not distorted by non-cash costs that are incurred whether or not the sale is made (project is conducted). Throughput should be used to estimate the cash flows that will result from a project.

Goldratt also defines two other financial metrics that managers need to consider to make good decisions. Investment (I) is defined as all the money spent by an organisation to purchase items it intends to turn into throughput - in other words the money spent on purchasing assets that will be reflected on the balance sheet. It will include assets such as inventory (more applicable in a production environment), equipment, machinery, plant, computers, etc. Operating Expenses (OE) is defined as all the money an organisation spends to turn Investment into Throughput. Examples are salaries, rentals, internet and electricity costs. OE is considered as fixed costs incurred in any case whether a sale is made or not - but may be affected in some way by conducting a project. The benefits resulting from a project is often justified by a cost saving (reduction on $\mathrm{OE}$ ) for example. The additional expenses incurred on a project (such as a labour contractor) are often shown as increased $\mathrm{OE}$ although strictly speaking it fits the definition of TVC better. A real change in OE must therefore be included in the valuation of the project.

The bottom line metrics for an organisation can be calculated as follows using these financial metrics:

Net profit $(\mathrm{NP})=$ Throughput $(\mathrm{T})-$ Operating Expense $(\mathrm{OE})$

Return on Investment $(\mathrm{ROI})=$ Net Profit (NP)/Investment (I)

ROI can also be viewed as a measurement of system productivity (or asset 
productivity). The outputs of the system (net profit) divided by the inputs into the system (investment - asset value).

The global project metrics must reflect the change of the organisational metric because the project is conducted. Then in the same way the impact of a project on the bottom line can be valuated as follows:

- Change in Throughput - the revenue (sales) (R) that result from a project deliverable minus the external costs (the true variable costs or TVC)) that are incurred in achieving that deliverable. This can be expressed as $\Delta \mathrm{T}=\Delta \mathrm{R}-\Delta \mathrm{TVC}$ (delta $\mathrm{T}=$ delta $\mathrm{R}$ - delta TVC), the change in Throughput for the organisation as a result of conducting the project or the money generated by the project or generated by achieving a deliverable on the project.

- Changes in Investment are the expenses that are incurred to create an asset if the product of the project would be an asset. It would include all the true variable costs on the project (materials, contractor fees, external labour costs, etc.) This is the money that would be capitalised to determine the value of the asset as stated by the balance sheet after the asset has been created for capital projects, for example. This can be expressed as $\Delta \mathrm{I}$, the change in Investment of the organisation and is equal to $\triangle \mathrm{TVC}$ when it is a capital project.

- Changes in Operating Expenses as a result of the project. This can be expressed as $\triangle \mathrm{OE}$, the change in Operating Expense of the organisation as a result of conducting the project.

The impact that a project has on the organisational bottom line is thus:

Change in profitability: $\Delta \mathrm{NP}=\Delta \mathrm{T}-\Delta \mathrm{OE}$.

The return on investment for the project: $\mathrm{ROI}=\Delta \mathrm{NP} / \Delta \mathrm{I}$.

This approach ensures that only real cash flows are used in the evaluation of a project, but does not account for the allocation of internal resources across projects.

\section{THROUGHPUT ACCOUNTING FOR PROJECT PORTFOLIOS}

Another central tenet of TOC is that the performance of the whole system depends on the performance of the weakest link or the system constraint - that resource that has the least or zero spare capacity [10]. This implies that to consider resource allocation, the impact of a project must be evaluated through assessing the effect it will have on the workload of the capacity constraint resource of the organisation. The capacity constrained resource translates to that resource that carries the heaviest workload in a multi-project environment.

Many resources are expected to cope with very high workloads in most of the multiproject cases that were studied. This is to ensure good performance on local performance metrics such as resource utilisation. Time sheets were used in a number of the cases studied to determine resource utilisation and to identify where excess capacity was available. Very few resources indicated excess capacity however and were actively looking for additional work to meet their high utilisation targets. A 
bonus system was linked to the achievement of utilisation targets in two of the cases, reinforcing this behaviour.

The practice in one of the cases studied was to choose one of the many candidates for constraint and use the workload of this resource to assess the impact of a new project. The assumption is that the impact will be similar on equally heavily loaded resources.

Throughput accounting [11] defines a metric of Throughput per the time the constraint works to produce a product, to prioritise new work. In a typical multiproject environment this metric would be Throughput per constraint day and would be determined by dividing the estimated workload of the constraint on a project into $\Delta \mathrm{T}$. If the project would cause significant changes in $\mathrm{OE}$, then a metric of $\Delta \mathrm{NP} /$ constraint day might be more valid to prioritise projects.

It is feasible to have the future estimated workload on a constrained resource estimated for all projects in a portfolio of projects from the schedules of the projects. In the early stages of valuation, before a project schedule can be done, the total workload on the constrained resource can be estimated to obtain an indication of its impact on the organisation capacity. A new proposed project could be evaluated in terms of its $\Delta \mathrm{T} /$ constraint day, compared with current values of other projects on this metric and then prioritised accordingly. A multi-project schedule based on the workload of the heavily loaded resource and the project priorities could then be defined, all projects can be staggered around this schedule, which would result in the effective scheduling of work for all other resources[11].

All the value metrics discussed are determined from estimates or predictions of an uncertain future. An accurate estimate is an oxymoron. None of the calculated metrics are accurate. The accuracy of the estimates and thus the metrics can be improved upon as better information becomes available. It implies that updated values of the metrics need to be available at the decision reviews of the project portfolio management process to again assess current projects together with new projects.

The variability inherent in the estimates and the effect of future decisions could be included in the valuation of a project by having two estimates of $\Delta \mathrm{NP}$, a pessimistic scenario and an optimistic scenario at a number of decision points built into a decision tree that models future decisions [13]. Each decision node in the tree would have the two branches; the pessimistic branches terminating relatively early while the optimistic branches continuing to a time horizon. The tree models the future decisions and need to be viewed as not having only the two possible outcomes, but that the two extreme outcomes include a reasonable range of possible outcomes. This model of the future could then be reviewed as part of the normal portfolio management process.

\section{CONCLUSION}

Management accounting for a portfolio of projects must provide managers with good financial information that can be combined with experience and insight to make 
decisions that will result in improved financial performance of the organisation. The questions that managers asked about projects when they have to select and prioritise; and the proposed throughput accounting tools that can be used to answer these questions are summarised in Table 2.

\begin{tabular}{|l|l|}
\hline Management questions about a project & Tools that can provide answer \\
\hline What is the value? & $\Delta \mathrm{NP}$ \\
\hline What are the risks? & Pessimistic and optimistic decision tree \\
\hline What is the investment required? & $\Delta \mathrm{I}$ \\
\hline What is the return on investment? & $\Delta \mathrm{NP} / \Delta \mathrm{I}$ \\
\hline How will resources be utilised? & $\Delta \mathrm{NP} /$ constraint day \\
\hline
\end{tabular}

Table 2: Throughput accounting tools

Only estimated cash flows are included in the answers provided by the decisionmaking tools. The answer is wrong, but the information is valid and fit for the intended use.

\section{REFERENCES}

[1] Kaplan, R.S. \& Norton, D.P. 2004. Strategy Maps, Boston: Harvard Business School Press, pp. 139.

[2] Thiry, M. 2002. Combining value and project management into an effective programme management model, International Journal of Project Management, 20, pp. 221-227

[3] Benko, C. \& McFarlan, F.W. 2003. Connecting the dots, Harvard Business School Press, pp. 3.

[4] Cooper, R.G. 1993. Winning at new products. Accelerating the process from idea to launch. $2^{\text {nd }}$ Edition. Addison-Wesley Publishing Company, pp 163.

[5] Kaplan, R.S. \& Norton, D.P, 2004. Strategy Maps, Boston: Harvard Business School Press, pp. 85 - 91.

[6] Luehrman, T. A. 1997. A general managers guide to valuation, Boston. Harvard Business Review, 75(3), May - June.

[7] Schlosser, M. 1992. Corporate Finance, $2^{\text {nd }}$ Edition. New York Prentice Hall.

[8] PMBOK ${ }^{\circledR}, 2000$. A guide to the Project Management Body of Knowledge, Project Management Institute, pp 83

[9] Luehrman, T. A. 1998. Investment opportunities as real options: Getting started on the numbers, Boston, Harvard Business Review, 76(4), July August.

[10] Goldratt, E.M. 1990. The Haystack Syndrome, North River Press.

[11] Noreen, E., Smith D. \& Mackey J.T. The Theory of Constraints and its implications for Management Accounting" Great Barrington. North River Press. 1995.

[12] Leach, L.P. 2000. Critical Chain Project Management, Artech House, pp. $183-197$.

[13] Schragenheim, E. 2004. Discussions of TOC Experts group. 